\title{
Integrating the Readiness and IS-Impact Constructs in the Rural Area Context: A Questionnaire Testing
}

\author{
Esa Firmansyah ${ }^{1}$, Yan Yan Sofyan ${ }^{2}$, Agun Guntara ${ }^{3}$, Dody Herdiana ${ }^{4}$, Mulya Suryadi ${ }^{5}$, Aedah \\ Binti Abd. Rahman ${ }^{6}$ \\ \{esa@stmik-sumedang.ac.id ${ }^{1}$, yanyan@stmik-sumedang.ac.id², aguntara@stmik-sumedang.ac.id ${ }^{3}$, \\ dody@stmik-sumedang.ac.id ${ }^{4}$, uthe@stmik-sumedang.ac.id ${ }^{5}$, aedah.abdrahman@aeu.edu.my ${ }^{6}$ \} \\ Department of Informatic Engineering STMIK Sumedang, Indonesia ${ }^{1,2,3,4,5}$, \\ School of Science and Technology Asia e University Malaysia ${ }^{6}$
}

\begin{abstract}
The purpose of this study is to examine the model of readiness and success of Rural ICT that is integrated with assessing the impact of Rural ICT use in Indonesia. Based on Rural ICT user data collected through surveys obtained, structural equation modeling (SEM) and path analysis were used to test the research model. The sample consisted of Rural ICT users from a number of villages in Indonesia. The research sample was obtained by distributing questionnaires through WA Group and e-mail, there were $80 \%$ of respondents filling out questionnaires from various stakeholders, respondents stated readiness in using Rural ICT. The results revealed that optimism and innovation had a positive effect on the use of the system. The quality of the system and the quality of information quality were found to be the main factors driving the use of the system. In addition, this study tries to provide a review of the literature from the latest studies published in the field of Rural ICT.
\end{abstract}

Keywords: Assessment, IS model, Technology Readiness, IS-Impact, ICT Rural Area.

\section{Introduction}

The use of ICT is found in almost all fields and has an impact on the development of the world, therefore an assessment of ICT is needed and an important research topic [1]. ICT is widely recognized as an important source for socio-economic progress in developed and developing countries [2]. By definition ICT refers to technology that provides access to information through telecommunications, but focuses on communication technology, including the Internet, wireless networks, cellphones, and other communication media [3]. The word ICT and Information System (IS) can be exchanged in the context of showing how to support the services of an organization, in this case the village government in Indonesia [4]. Administrative management in rural areas is currently required to use information systems [5], several studies of information systems have noted that there has been an increase in demand for information systems relating to rural areas. [2, 5-7]. The rapid spread of mobile phones, the internet, and the use of IS have encouraged considerable investment, this is estimated to have contributed to the growth of the world economy [8]. However, on the other hand in particular at a more practical level that the information system is allegedly unable to solve problems that occur in rural communities, especially in improving the welfare of the community [9]. Therefore, further research is needed in the context of testing with questionnaires to stakeholders. Many IS survey 
studies previously used questionnaires adopted and adapted from previous works [10-15]. This relates to the question of whether the new instrument is suitable for this study. On the other hand, technological developments have developed since the beginning of the study [16]. In addition, instrument assessment still tends to be the only stage to evaluate whether the respondent has a problem responding to the questionnaire [17].

The use of statistical analysis in measuring this model is based on each indicator of each variable. The purpose of this questionnaire is to measure statistically from a model that has been previously made, with the hope that this research will enrich and provide input for future researchers who will test models of information systems in rural areas. Therefore, the following research questions will provide guidance on the conduct of this research:

T1. What are the effects of the readiness and success of Rural ICT?

T2. What are the results of the Rural ICT assessment in terms of readiness and success in changing existing variables and indicators?

Next in sequence, this paper explains the theoretical framework used in research. The next part is the implementation of the research methodology. Then proceed with a discussion of the results of research and discussion. While the conclusion is the end of this paper, which is the concluding section.

\section{Research Method}

The research method used consisted of a preliminary study (ie a review of the literature on the readiness and impact of the Information System, the development of the Information Systems model, and studies on the development of its instruments). Furthermore, sequentially starting from determining the research program, developing models from previous models, developing research models, developing instruments, applying research instruments, the process of collecting data, then analyzed according to needs, then the results of the analysis are interpreted and written as the results of the analysis and as a report. for more clearly can be seen in Figure 1. Then the model that has been made before (Figure 2), produces a questionnaire that must be evaluated.

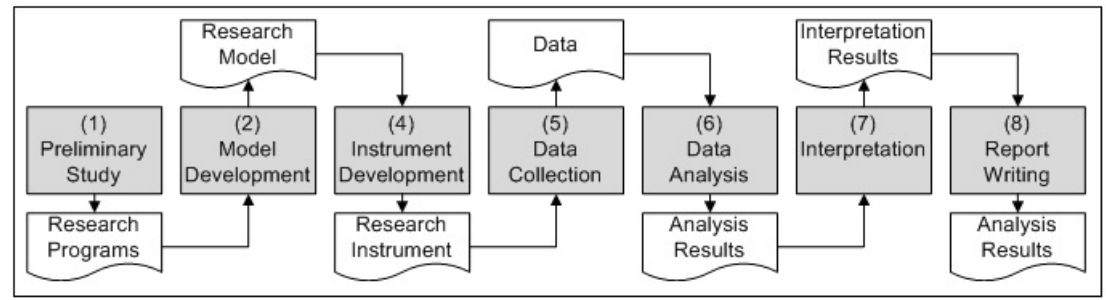

Figure 1. The Research Procedure [18]

This study measures the readiness model and impact of success with a questionnaire (Figure 2). Measurement of the model used is indirectly inspired by the measurement of models that many other researchers [15], such as the development of models carried out by Antara and Mertz [19, 20], viewed from the practical side that Information Systems research tends to be developed from previous models rather than based on empirical studies[21]. Therefore the measurement of the model in this study follows the previous researchers with the following stages, namely by adopting, combining, and adapting the previous model [22-24], The following 
nine variables are used in this study, consisting of four readiness variables and five information system impact variables. First is Optimistic attitude (OPT), second is innovative attitude (INV), third is discomfort attitude (DCF), and fourth is Insecurity attitude (ISC), fifth is Individual Impact (II), sixth is Organizational Impact (OI), seventh is the Quality System (SQ), the eighth is Information Quality (IQ), and the ninth is the Impact of a successful Information System (ISImpact). The first four variables are adopted from the Technology Readiness Model[22] and the other from the IS success model[12, 15, 23, 25, 26]. The results of the development of models that have been developed previously in the form of questionnaires derived from variables and indicators can be seen in the model (Figure 2) and (Tables 1and 2).

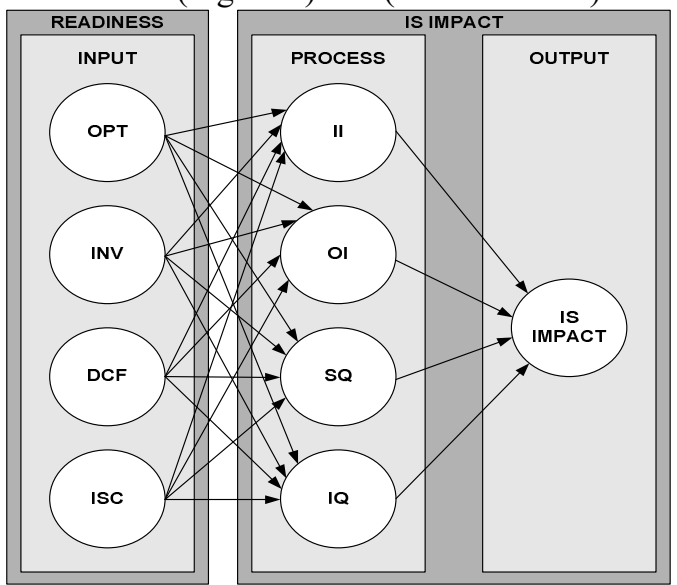

Figure 2. The Integrating the Readiness and IS-Impact Model [21]

The questionnaire was distributed as many as 80 copies online, which was distributed based on the respondents' profile experience. Questionnaires are distributed through WA Group and e-mail to fill in the questionnaire form that has been made. Then the researchers processed the data based on the incoming form using SmartPLS 2.0. then the PLS-SEM method is used in the analysis phase to determine indicators of reliability, internal consistency reliability, convergent validity, and discriminant validity assessment.

Table 1. List of the questions $[21-23,27,28]$

\begin{tabular}{ll}
\hline Code & \\
\hline OPT1 & This system is free from problems of use \\
OPT2 & The system can communicate with other systems \\
OPT3 & The system runs even at low specifications \\
OPT4 & The system works to the maximum \\
OPT5 & The system operates efficiently and effectively \\
INV1 & The system can solve problems \\
INV2 & The system can help users \\
INV3 & The system supports users \\
INV4 & The system helps users in achieving goals \\
INV5 & The system supports users to be more successful \\
DCF1 & The system confuses users \\
DCF2 & The system is difficult to use \\
DCF3 & The system is operated with limited \\
DCF4 & The system is not fully supported \\
\hline
\end{tabular}




\begin{tabular}{|c|c|}
\hline Code & Questionnaires \\
\hline DCF5 & The system is not according to plan \\
\hline ISC1 & The system is not in accordance with its development planning \\
\hline ISC2 & The system can cause danger \\
\hline ISC3 & The system interacts less \\
\hline ISC4 & The system out of focus \\
\hline ISC5 & The system is doubtful \\
\hline II1 & The system can produce something new \\
\hline II 2 & The system can know or remember \\
\hline II 3 & The system can produce decisions that can solve problems \\
\hline II4 & The system can determine productivity and behavior directly \\
\hline OI1 & The system requires an initial fee \\
\hline OI2 & The system consists of job categories \\
\hline OI3 & The system can reduce costs and increase their profits. \\
\hline OI4 & The system produces goods or services \\
\hline OI5 & The system can improve the quality and cost of health care organizations \\
\hline SQ1 & The system can increase activities or processes to gain knowledge or skills \\
\hline SQ2 & The system is free from obstacles, difficulties, and problems during its use \\
\hline SQ3 & The system can obtain, check, or retrieve (data or files) \\
\hline SQ4 & The system is used in determining the expectations software users do \\
\hline SQ5 & The system has the characteristics of goods or services \\
\hline IQ1 & The system can be an important or valuable fact. \\
\hline IQ2 & The system has qualities that can be used. \\
\hline IQ3 & The system is suitable for use \\
\hline IQ4 & The system can be arranged \\
\hline IQ5 & The system processes data from the same or different sources \\
\hline ISI1 & The system can compare IS results and resources \\
\hline ISI2 & The system has the ability to meet the needs of users in achieving their goals \\
\hline ISI3 & The system can help users in creating their business \\
\hline ISI4 & The system can support the increase in output compared to the resources needed \\
\hline ISI5 & An integrated system can benefit business competition \\
\hline
\end{tabular}

Table 2. List of variables and indicators [21]

\begin{tabular}{cl}
\hline Variables & \multicolumn{1}{c}{ Indicators } \\
\hline Optimism & Easy, connection, efficient, effective, productive. \\
Innovation & solving problems, being independent, accepting challenges, receiving stimulation, having competitiveness \\
Discomfort & Complex, have difficulty, dependence on the system, lack of support, less accurate \\
Insecurity & Failure can occur, there can be threats, reduce interaction, have disturbances, are doubtful \\
Individual & Enhance learning, increase awareness, increase Decision Effectiveness, increase Individual Productivity \\
Impact & \\
Organization & increase organizational costs, raises staff requirements, reduce operational costs, increase productivity, \\
Impact & better results \\
System & Easy to learn, easy to use, easy to access, requires user requirements, complete system features \\
Quality & \\
Information & The Importance of Information, Availability of Information, Usefulness of Information, Format of \\
Quality & Information, Accuracy of Information \\
Information & Efficient information systems, effective information systems, information systems that satisfy users, \\
System & information systems that can increase productivity, information systems that can enhance competitive \\
Impact & advantage \\
\hline
\end{tabular}




\section{Result and Discussion}

\subsection{Demographic Information}

The following table 3 will present the characteristics of respondents based on education, skill level, position, and experience in terms of IS-Impact Rural. While Table 4 below shows the characteristics of respondents based on readiness and IS-Impact in rural areas of Indonesia. These results are expected to provide recommendations for further researchers.

Table 3. Profile of questionnaire respondents

\begin{tabular}{ccc}
\hline Measures & Items & $\%$ \\
\hline Education & High School & 75.4 \\
& Diploma & 1.6 \\
& Bachelor & 9.3 \\
& Master & 13.1 \\
& Doctor & 0.5 \\
Position & Top Level Leader & 1.6 \\
& Middle Level Leader & 4.9 \\
& Staff & 9.8 \\
\hline
\end{tabular}

Table 4. Readiness and IS-Impact profiles

\begin{tabular}{|c|c|c|}
\hline Measures & Items & $\%$ \\
\hline Optimistic Status of readiness and & free from obstacles & 87 \\
\hline \multirow[t]{4}{*}{ IS-Impact Rural in Indonesia } & easily connected to other systems & 82 \\
\hline & operate in minimal resources & 56 \\
\hline & operate at maximum results & 82 \\
\hline & efficiently and effectively & 91 \\
\hline Innovative Status of Rural & problem-solving tool & 87 \\
\hline Readiness and IS-Impact in & help users to be free & 61 \\
\hline \multirow[t]{3}{*}{ Indonesia } & support users to achieve goals & 90 \\
\hline & achieve goals & 83 \\
\hline & users success & 85 \\
\hline Discomfort Status of Rural & confuse users in their operations & 84 \\
\hline Readiness and IS-Impact in & difficult to operate easily & 90 \\
\hline \multirow[t]{3}{*}{ Indonesia } & limited operation & 86 \\
\hline & operated without full support & 82 \\
\hline & accordance without planning & 92 \\
\hline Insecurity Status of Rural & not been successfully operated & 83 \\
\hline Readiness and IS-Impact in & situations that can be danger & 79 \\
\hline \multirow[t]{3}{*}{ Indonesia } & make users less interacting & 78 \\
\hline & makes users not focus & 73 \\
\hline & doubtful to use & 83 \\
\hline Individual Impact Status of Rural & get something new & 78 \\
\hline Readiness and IS-Impact in & feeling knowing or remembering & 85 \\
\hline \multirow[t]{2}{*}{ Indonesia } & decisions that can solve problems & 90 \\
\hline & determining productivity & 87 \\
\hline Organizational Impact Status of & Initial costs & 46 \\
\hline Rural Readiness and IS-Impact in & Degrees related to job categories & 63 \\
\hline \multirow[t]{3}{*}{ Indonesia } & reduce costs and increase profits & 80 \\
\hline & services of ability & 79 \\
\hline & quality and cost & 87 \\
\hline System Quality Status of Rural & level of activities or processes & 66 \\
\hline Readiness and IS-Impact in & level of freedom from obstacles & 75 \\
\hline \multirow[t]{3}{*}{ Indonesia } & Degrees related data or files & 68 \\
\hline & documents & 85 \\
\hline & Degrees of characteristics & 83 \\
\hline
\end{tabular}




\begin{tabular}{lcc}
\hline \multicolumn{1}{c}{ Measures } & Items & $\%$ \\
\hline Information Quality Status of & facts become very important & 85 \\
Rural Readiness and IS-Impact in & Quality can be used or obtained & 63 \\
Indonesia & suitable for use & 72 \\
& arranged or established & 73 \\
& level of how data is collected & 82 \\
Information System Impact & comparison of the value & 75 \\
Status of Rural Indonesia & level associated with the ability & 87 \\
& create value for business & 86 \\
& support is to increase output & 86 \\
& compete in business competition & 79 \\
\hline
\end{tabular}

Table 4 shows an overview of the characteristics of respondents in the readiness and ISImpact questionnaire in rural areas of Indonesia. These results are expected to provide recommendations for further researchers.

\subsection{Results of Statistical Analysis}

The results of the statistical analysis consist of several stages, the first stage is evaluating the reflective measurement model and evaluating the structural model. Where the evaluation of this reflective measurement is the stage of evaluating the value of reliability of internal consistency using Composite Reliability (Table 4 and Table 6), the next step is evaluating the Reliability Indicator indicated by (Table 5), Convergence Validity is contained in (Table 7), while Discriminant Validity is shown in (Table 8). Structural Model Evaluation is the stage in determining whether a hypothesis can be based on the research model (Table 9), then assesses $\mathrm{R} 2$ which is an endogenous latent variable in the pathway model shown by (Table 10) and the last stage is the assessment of the contribution of exogenous constructs to the latent variable endogenous ones shown in (Table 11).

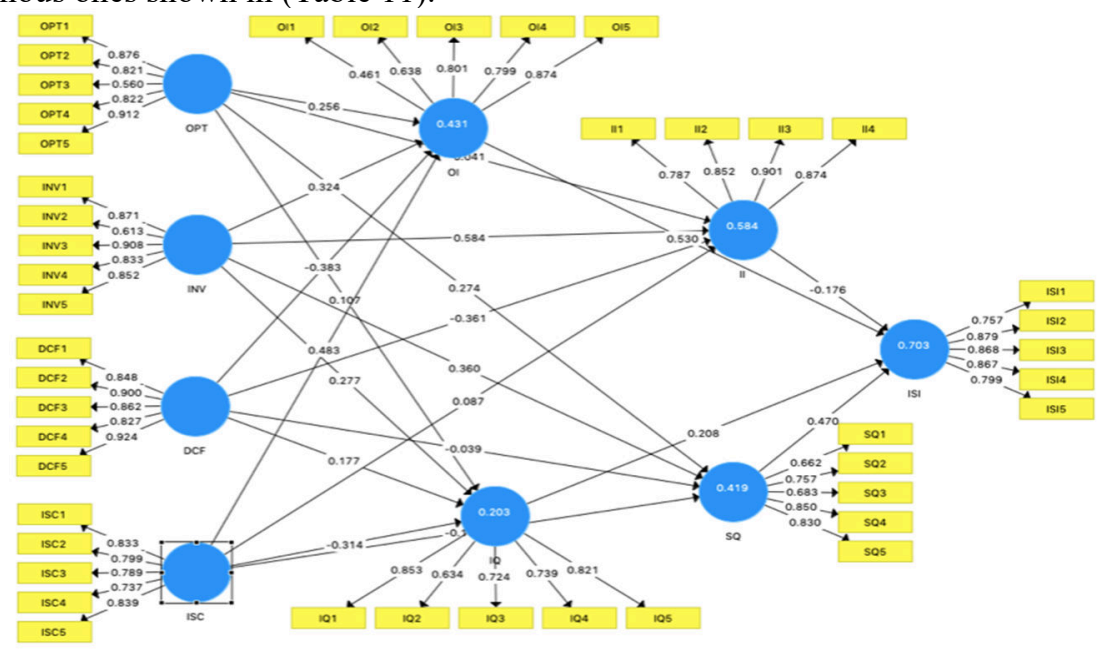

Figure 3. Research model Readiness and Impact (ISRI)

Table 5. Construct reliability and validity ISRI Model

\begin{tabular}{ccccc}
\hline & Cronbach's Alpha & rho_A & Composite Reliability & Average Variance Extracted (AVE) \\
\hline DCF & 0.922 & 0.927 & 0.941 & 0.762 \\
II & 0.876 & 0.884 & 0.915 & 0.730 \\
INV & 0.875 & 0.889 & 0.911 & 0.676 \\
IQ & 0.814 & 0.836 & 0.870 & 0.575
\end{tabular}




$\begin{array}{ccccc}\text { ISC } & 0.862 & 0.894 & 0.899 & 0.640 \\ \text { ISI } & 0.891 & 0.896 & 0.920 & 0.698 \\ \text { OI } & 0.770 & 0.821 & 0.845 & 0.533 \\ \text { OPT } & 0.859 & 0.878 & 0.902 & 0.652 \\ \text { SQ } & 0.816 & 0.830 & 0.871 & 0.578\end{array}$

Table 5 shows the composite reliability for all reflective constructions higher than 0.708 , this shows that the reliability of internal consistency has a high value.

Table 6. Outer loadings ISRI Model

\begin{tabular}{|c|c|c|c|c|c|c|c|c|c|}
\hline & DCF & II & INV & IQ & ISC & ISI & OI & OPT & SQ \\
\hline DCF1 & 0.848 & & & & & & & & \\
\hline DCF2 & 0.900 & & & & & & & & \\
\hline DCF3 & 0.862 & & & & & & & & \\
\hline DCF4 & 0.827 & & & & & & & & \\
\hline DCF5 & 0.924 & & & & & & & & \\
\hline II1 & & 0.787 & & & & & & & \\
\hline II2 & & 0.852 & & & & & & & \\
\hline II3 & & 0.901 & & & & & & & \\
\hline II4 & & 0.874 & & & & & & & \\
\hline INV1 & & & 0.871 & & & & & & \\
\hline INV2 & & & 0.613 & & & & & & \\
\hline INV3 & & & 0.908 & & & & & & \\
\hline INV4 & & & 0.833 & & & & & & \\
\hline INV5 & & & 0.852 & & & & & & \\
\hline IQ1 & & & & 0.853 & & & & & \\
\hline IQ2 & & & & 0.634 & & & & & \\
\hline IQ3 & & & & 0.724 & & & & & \\
\hline IQ4 & & & & 0.739 & & & & & \\
\hline IQ5 & & & & 0.821 & & & & & \\
\hline ISC 1 & & & & & 0.833 & & & & \\
\hline ISC2 & & & & & 0.799 & & & & \\
\hline ISC3 & & & & & 0.789 & & & & \\
\hline ISC4 & & & & & 0.737 & & & & \\
\hline ISC5 & & & & & 0.839 & & & & \\
\hline ISI1 & & & & & & 0.757 & & & \\
\hline ISI2 & & & & & & 0.879 & & & \\
\hline ISI3 & & & & & & 0.868 & & & \\
\hline ISI4 & & & & & & 0.867 & & & \\
\hline ISI5 & & & & & & 0.799 & & & \\
\hline OI1 & & & & & & & 0.461 & & \\
\hline OI2 & & & & & & & 0.638 & & \\
\hline OI3 & & & & & & & 0.801 & & \\
\hline OI4 & & & & & & & 0.799 & & \\
\hline OI5 & & & & & & & 0.874 & & \\
\hline OPT1 & & & & & & & & 0.876 & \\
\hline OPT2 & & & & & & & & 0.821 & \\
\hline OPT3 & & & & & & & & 0.560 & \\
\hline OPT4 & & & & & & & & 0.822 & \\
\hline OPT5 & & & & & & & & 0.912 & \\
\hline SQ1 & & & & & & & & & 0.662 \\
\hline SQ2 & & & & & & & & & 0.757 \\
\hline SQ3 & & & & & & & & & 0.683 \\
\hline SQ4 & & & & & & & & & 0.850 \\
\hline SQ5 & & & & & & & & & 0.830 \\
\hline
\end{tabular}

Table 6 shows that the IQ2, OI1, OI2, SQ1, and SQ3, OPT3 indicators have values below 0.708 , so the five indicators in this model need to be analyzed in relation to the deletion effect on the indicators found on AVE and the composite reliability shown by (Table 5). Therefore, if the release can increase the measurement, the reflective indicator needs to be removed from the 
model, but if elimination cannot increase the measurement, then the reflective indicator needs to be maintained because it matches the criteria.

Table 7. Composite reliability from ISRI Models

\begin{tabular}{ccc}
\hline Composite Reliability & Full Model & $\begin{array}{c}\text { Model Revision } \\
\text { (Deletion Indicator IQ2, OI1, OI2, SQ1, and SQ3, OPT3, INV2) }\end{array}$ \\
\hline DCF & 0.941 & 0.761 \\
II & 0.915 & 0.731 \\
INV & 0.911 & 0.773 \\
IQ & 0.870 & 0.648 \\
ISC & 0.899 & 0.639 \\
ISI & 0.920 & 0.698 \\
OI & 0.845 & 0.740 \\
OPT & 0.902 & 0.761 \\
SQ & 0.871 & 0.730 \\
\hline
\end{tabular}

Table 8. Convergent validity from ISRI Models

\begin{tabular}{ccc}
\hline AVE & Full Model & $\begin{array}{c}\text { Model Revision } \\
\text { (Deletion Indicator IQ2, OI1, OI2, SQ1, and SQ3, OPT3, INV2) }\end{array}$ \\
\hline DCF & 0.762 & 0.684 \\
II & 0.730 & 0.908 \\
INV & 0.676 & 0.687 \\
IQ & 0.575 & 0.737 \\
ISC & 0.640 & 0.766 \\
ISI & 0.698 & 0.761 \\
OI & 0.533 & 0.753 \\
OPT & 0.652 & 0.740 \\
SQ & 0.578 & 0.817 \\
\hline
\end{tabular}

Table 7 shows that the removal of IQ2, OI1, OI2, SQ1, and SQ3, OPT3, INV2 indicators shows an increase in the value of composite reliability. Because the AVE value on all variables shows a number higher than 0.5 , it can be concluded that the convergent validity can be confirmed. While Table 8 shows that all external indicators contain higher construction values compared to other construction values, this explains that the discriminant validity can be confirmed [39].

Table 9 shows that a hypothesis is based on a research model. Therefore, in assessing the significance of the path coefficient and the 5\% significance level, one-way testing is used, so that the significance level is 1.64 .

Table 10 shows the R2 values which are the endogenous constructs of each variable, namely Optimism and Innovation, each of which is substantial. While the endogenous construct of the Efficiency and Discomfort variable shows a weak value. While the endogenous construct of Organizational Impacts, Satisfaction has a moderate value. Meanwhile Table 11 shows all the contributions of exogenous constructs to their endogenous latent variables [39]. 
Table 9. Cross loadings of ISRI Model revision

\begin{tabular}{|c|c|c|c|c|c|c|c|c|c|}
\hline DCF1 & 0.854 & -0.450 & -0.337 & -0.092 & 0.378 & -0.571 & -0.464 & -0.503 & -0.452 \\
\hline DCF2 & 0.901 & -0.396 & -0.178 & -0.103 & 0.646 & -0.310 & -0.177 & -0.280 & -0.337 \\
\hline DCF3 & 0.862 & -0.459 & -0.326 & -0.122 & 0.497 & -0.396 & -0.251 & -0.338 & -0.335 \\
\hline DCF4 & 0.819 & -0.426 & -0.265 & -0.266 & 0.558 & -0.400 & -0.158 & -0.417 & -0.256 \\
\hline DCF5 & 0.923 & -0.439 & -0.274 & -0.126 & 0.688 & -0.354 & -0.174 & -0.430 & -0.311 \\
\hline II1 & -0.418 & 0.791 & 0.492 & 0.499 & -0.231 & 0.508 & 0.599 & 0.416 & 0.439 \\
\hline II2 & -0.421 & 0.855 & 0.568 & 0.317 & -0.276 & 0.494 & 0.585 & 0.489 & 0.402 \\
\hline II3 & -0.418 & 0.899 & 0.600 & 0.332 & -0.222 & 0.446 & 0.631 & 0.494 & 0.494 \\
\hline II4 & -0.451 & 0.870 & 0.657 & 0.466 & -0.267 & 0.594 & 0.667 & 0.444 & 0.559 \\
\hline INV1 & -0.233 & 0.599 & 0.878 & 0.367 & -0.218 & 0.510 & 0.412 & 0.491 & 0.487 \\
\hline INV3 & -0.325 & 0.604 & 0.925 & 0.215 & -0.224 & 0.462 & 0.433 & 0.568 & 0.453 \\
\hline INV4 & -0.365 & 0.613 & 0.842 & 0.346 & -0.291 & 0.394 & 0.318 & 0.494 & 0.434 \\
\hline INV5 & -0.222 & 0.581 & 0.868 & 0.316 & -0.133 & 0.525 & 0.446 & 0.457 & 0.532 \\
\hline IQ1 & 0.021 & 0.397 & 0.343 & 0.831 & -0.054 & 0.605 & 0.413 & 0.110 & 0.446 \\
\hline IQ3 & -0.289 & 0.262 & 0.155 & 0.768 & -0.440 & 0.420 & 0.056 & 0.315 & 0.332 \\
\hline IQ4 & -0.173 & 0.323 & 0.153 & 0.792 & -0.365 & 0.275 & 0.050 & 0.276 & 0.266 \\
\hline IQ5 & -0.112 & 0.501 & 0.420 & 0.827 & -0.172 & 0.578 & 0.410 & 0.280 & 0.600 \\
\hline ISC1 & 0.691 & -0.333 & -0.222 & -0.276 & 0.841 & -0.349 & -0.019 & -0.401 & -0.409 \\
\hline ISC2 & 0.486 & -0.103 & -0.179 & -0.247 & 0.799 & -0.164 & 0.094 & -0.156 & -0.155 \\
\hline ISC 3 & 0.355 & -0.133 & -0.117 & -0.175 & 0.785 & -0.115 & 0.114 & -0.080 & -0.211 \\
\hline ISC4 & 0.238 & -0.137 & -0.084 & -0.244 & 0.729 & -0.100 & 0.111 & 0.036 & -0.215 \\
\hline ISC5 & 0.568 & -0.345 & -0.320 & -0.218 & 0.838 & -0.177 & 0.038 & -0.456 & -0.234 \\
\hline ISI1 & -0.380 & 0.411 & 0.489 & 0.305 & -0.229 & 0.761 & 0.466 & 0.414 & 0.614 \\
\hline ISI2 & -0.355 & 0.548 & 0.469 & 0.652 & -0.195 & 0.875 & 0.556 & 0.371 & 0.521 \\
\hline ISI3 & -0.512 & 0.621 & 0.509 & 0.438 & -0.193 & 0.871 & 0.677 & 0.486 & 0.632 \\
\hline ISI4 & -0.437 & 0.421 & 0.430 & 0.457 & -0.197 & 0.872 & 0.502 & 0.480 & 0.624 \\
\hline ISI5 & -0.306 & 0.493 & 0.359 & 0.685 & -0.236 & 0.790 & 0.465 & 0.303 & 0.552 \\
\hline OI3 & -0.261 & 0.569 & 0.397 & 0.224 & 0.101 & 0.565 & 0.828 & 0.318 & 0.275 \\
\hline OI4 & -0.250 & 0.550 & 0.235 & 0.197 & 0.063 & 0.488 & 0.854 & 0.388 & 0.260 \\
\hline OI5 & -0.258 & 0.742 & 0.521 & 0.392 & 0.014 & 0.594 & 0.898 & 0.469 & 0.272 \\
\hline OPT1 & -0.365 & 0.502 & 0.414 & 0.425 & -0.286 & 0.372 & 0.385 & 0.894 & 0.352 \\
\hline OPT2 & -0.453 & 0.487 & 0.485 & 0.266 & -0.393 & 0.288 & 0.268 & 0.844 & 0.303 \\
\hline OPT4 & -0.299 & 0.432 & 0.514 & 0.117 & -0.176 & 0.482 & 0.535 & 0.830 & 0.432 \\
\hline OPT5 & -0.496 & 0.462 & 0.582 & 0.226 & -0.245 & 0.559 & 0.388 & 0.917 & 0.479 \\
\hline SQ2 & -0.326 & 0.435 & 0.564 & 0.239 & -0.234 & 0.618 & 0.284 & 0.478 & 0.870 \\
\hline SQ4 & -0.129 & 0.444 & 0.349 & 0.626 & -0.258 & 0.480 & 0.172 & 0.287 & 0.818 \\
\hline SQ5 & -0.501 & 0.545 & 0.453 & 0.560 & -0.349 & 0.676 & 0.320 & 0.371 & 0.875 \\
\hline
\end{tabular}

Table 10. Assessment of the significance of path coefficients on the ISRI Model

\begin{tabular}{ccccccc}
\hline & $\begin{array}{c}\text { Original } \\
\text { Sample } \\
(\mathrm{O})\end{array}$ & $\begin{array}{c}\text { Sample } \\
\text { Mean }(\mathrm{M})\end{array}$ & $\begin{array}{c}\text { Standard } \\
\text { Deviation } \\
(\text { STDEV })\end{array}$ & $\begin{array}{c}\text { T Statistics } \\
(\mid \mathrm{O} / \text { STDEV } \mid)\end{array}$ & P Values & Results \\
\hline DCF -> II & -0.361 & 0.059 & 0.224 & 0.281 & 0.779 & Insignificant \\
DCF -> IQ & -0.232 & -0.230 & 0.188 & 1.237 & 0.216 & Insignificant \\
DCF -> OI & -0.407 & -0.401 & 0.165 & 2.471 & 0.014 & Significant \\
DCF -> SQ & -0.305 & -0.307 & 0.198 & 1.538 & 0.125 & Insignificant \\
II -> ISI & -0.131 & -0.141 & 0.187 & 0.702 & 0.483 & Insignificant \\
INV -> II & -0.123 & -0.120 & 0.168 & 0.730 & 0.466 & Insignificant \\
INV -> IQ & 0.147 & 0.153 & 0.122 & 1.201 & 0.230 & Insignificant \\
INV -> OI & 0.349 & 0.365 & 0.134 & 2.603 & 0.010 & Significant \\
INV - > SQ & 0.269 & 0.259 & 0.152 & 1.769 & 0.077 & Significant \\
IQ -> ISI & 0.194 & 0.200 & 0.129 & 1.497 & 0.135 & Insignificant \\
ISC -> II & 0.275 & 0.270 & 0.136 & 2.021 & 0.044 & Significant \\
ISC -> IQ & 0.228 & 0.231 & 0.150 & 1.518 & 0.130 & Insignificant \\
ISC -> OI & 0.257 & 0.281 & 0.118 & 2.169 & 0.031 & Significant \\
ISC -> SQ & -0.230 & -0.207 & 0.193 & 1.053 & 0.293 & Insignificant \\
OI -> ISI & -0.051 & -0.068 & 0.190 & 0.266 & 0.790 & Insignificant
\end{tabular}




\begin{tabular}{ccccccc}
\hline & $\begin{array}{c}\text { Original } \\
\text { Sample } \\
(\mathrm{O})\end{array}$ & $\begin{array}{c}\text { Sample } \\
\text { Mean (M) }\end{array}$ & $\begin{array}{c}\text { Standard } \\
\text { Deviation } \\
(\text { STDEV })\end{array}$ & $\begin{array}{c}\text { T Statistics } \\
(\mid \mathrm{O} / \text { STDEV } \mid)\end{array}$ & P Values & Results \\
\hline OPT -> II & -0.034 & -0.033 & 0.188 & 0.182 & 0.856 & Insignificant \\
OPT -> IQ & -0.108 & -0.110 & 0.185 & 0.582 & 0.561 & Insignificant \\
OPT -> OI & -0.154 & -0.162 & 0.193 & 0.796 & 0.426 & Insignificant \\
OPT -> SQ & -0.140 & -0.147 & 0.144 & 0.971 & 0.332 & Insignificant \\
SQ -> ISI & 0.129 & 0.109 & 0.144 & 0.895 & 0.371 & Insignificant \\
\hline
\end{tabular}

Table 11. R Square

\begin{tabular}{ccc}
\hline & R Square & R Square Adjusted \\
\hline II & 0.563 & 0.510 \\
IQ & 0.193 & 0.095 \\
ISI & 0.744 & 0.713 \\
OI & 0.394 & 0.321 \\
SQ & 0.366 & 0.289 \\
\hline
\end{tabular}

Table 12. F- Square

\begin{tabular}{|c|c|c|c|c|c|c|c|c|c|}
\hline & DCF & II & INV & IQ & ISC & ISI & OI & OPT & SQ \\
\hline $\begin{array}{c}\text { DCF } \\
\text { II }\end{array}$ & & 0.128 & & 0.019 & & 0.055 & 0.112 & & 0.018 \\
\hline $\begin{array}{c}\text { INV } \\
\text { IQ }\end{array}$ & & 0.435 & & 0.056 & & 0.172 & 0.103 & & 0.169 \\
\hline $\begin{array}{l}\text { ISC } \\
\text { ISI }\end{array}$ & & 0.007 & & 0.066 & & & 0.199 & & 0.010 \\
\hline OI & & & & & & 0.536 & & & \\
\hline $\begin{array}{c}\text { OPT } \\
\text { SQ }\end{array}$ & & 0.016 & & 0.014 & & 0.584 & 0.064 & & 0.014 \\
\hline
\end{tabular}

\section{Conclussion}

The conclusion of this research is to measure the model with a questionnaire in conducting statistical analysis through the values of validity and reliability that are used as a reference in revising the model that was built before going through the stages of integration and adoption of several previous models. The results of this study did not change the model and questionnaire, this was caused by the validity and reliability values that were in accordance with the criteria. However, this can be used as a reference for further researchers who are interested in developing and measuring it further.

Therefore greater attention is needed in relation to the sample used, bearing in mind that the sample used in this study is only in rural areas of Indonesia, so it would be better for other researchers to try to apply the measurement model that was constructed including various questionnaires.

\section{References}

[1] S. H. Doong and S.-C. Ho, "The impact of ICT development on the global digital divide," Electronic Commerce Research and Applications, vol. 11, no. 5, pp. 518-533, 2012. 
[2] K. Salemink, D. Strijker, and G. J. J. o. R. S. Bosworth, "Rural development in the digital age: A systematic literature review on unequal ICT availability, adoption, and use in rural areas," vol. 54, pp. 360-371, 2017.

[3] M. M. Lloyd, "Towards a definition of the integration of ICT in the classroom," 2005.

[4] X. Xu, W. Zhang, and R. Barkhi, "IT infrastructure capabilities and IT project success: a development team perspective," Information Technology and Management, vol. 11, no. 3, pp. 123-142, 2010.

[5] M. Badri, "Pembangunan pedesaan Berbasis Teknologi Informasi dan Komunikasi (Studi Pada Gerakan Desa Membangun)," RISALAH, vol. 27, no. 2, pp. 62-73, 2016.

[6] B. J. J. S. K. d. M. Sunarwan, "Pola Penggunaan Teknologi Informasi Dan Komunikasi (Tik) di Lingkungan Masyarakatpedesaan (Survei Pada Komunitas Anggota Penerima PNPM Provinsi Jambi)," vol. 17, no. 2, pp. 149-162, 2013.

[7] L. P. Pant and H. H. J. J. o. R. S. Odame, "Broadband for a sustainable digital future of rural communities: A reflexive interactive assessment," vol. 54, pp. 435-450, 2017.

[8] D. W. Jorgenson and K. M. J. T. P. Vu, "The ICT revolution, world economic growth, and policy issues," vol. 40, no. 5, pp. 383-397, 2016.

[9] A. Noor Asyikin, R. Fitri, and A. SBN, "Pengukuran Tingkat Kesiapan Kantor Pemerintahan Desa Dalam Penerapan Masterplan Teknologi Informasi Dan Komunikasi (Tik) Perkantoran Desa Menggunakan Kerangka Kerja Cobit 4.1," Jurnal Poros Teknik, vol. 7, no. 2, pp. 61-67, 2015.

[10] W. Waheduzzaman and S. J. Miah, "Readiness assessment of e-government: a developing country perspective," Transforming Government: People, Process and Policy, vol. 9, no. 4, pp. 498-516, 2015.

[11] A. Subiyakto, A. R. Ahlan, M. Kartiwi, and H. T. Sukmana, "Influences of the Input Factors towards Success of An Information System Project," TELKOMNIKA (Telecommunication Computing Electronics and Control), vol. 13, no. 2, pp. 686-693, June, 20152015.

[12] A. Subiyakto and A. R. Ahlan, "Implementation of Input-Process-Output Model for Measuring Information System Project Success," TELKOMNIKA Indonesian Journal of Electrical Engineering, vol. 12, no. 7, pp. 5603-5612, 20142014.

[13] T. Remencius, A. Sillitti, and G. Succi, "Assessment of software developed by a thirdparty: A case study and comparison," Information Sciences, vol. 328, pp. 237-249, 2016.

[14] S. Nambisan, "Information technology and product/service innovation: A brief assessment and some suggestions for future research," Journal of the Association for Information Systems, vol. 14, no. 4, p. 215, 2013.

[15] A. Alshardan, R. Goodwin, and G. Rampersad, "A benefits assessment model of information systems for small organizations in developing countries," Computer and Information Science, vol. 9, no. 1, p. 1, 2015.

[16] B. Sandra and F. Brenton, "Developers, Decision Makers, Strategists or Just Endusers? Redefining End-User Computing for the 21st Century: A Case Study," Journal of Organizational and End User Computing (JOEUC), vol. 23, no. 2, pp. 1-14, 2011.

[17] S. Presser et al., "Methods for testing and evaluating survey questions," Public opinion quarterly, vol. 68, no. 1, pp. 109-130, 2004.

[18] A. J. B. E. E. I. Subiyakto, "Assessing information system integration using combination of the readiness and success models," vol. 7, pp. 400-410, 2018.

[19] V. A. Anfara Jr and N. T. Mertz, Theoretical frameworks in qualitative research. Sage publications, 2014. 
[20] A. Belout and C. Gauvreau, "Factors influencing project success: the impact of human resource management," International journal of project management, vol. 22, no. 1, pp. 1-11, 2004.

[21] E. Firmansyah, D. Yuniarto, D. Herdiana, M. Suryadi, A. Subiyakto, and A. Rahman, "Integrating the Readiness and IS-Impact Constructs in the Rural Area Context: A Model Development," in IOP Conference Series: Materials Science and Engineering, 2019, vol. 662, no. 2, p. 022064: IOP Publishing.

[22] A. Parasuraman and C. L. Colby, "An updated and streamlined technology readiness index: TRI 2.0," Journal of service research, vol. 18, no. 1, pp. 59-74, 2015.

[23] W. H. DeLone and E. R. McLean, "The DeLone and McLean model of information systems success: a ten-year update," Journal of management information systems, vol. 19, no. 4, pp. 9-30, 2003.

[24] M. Irfan, S. Putra, C. Alam, A. Subiyakto, and A. Wahana, "Readiness factors for information system strategic planning among universities in developing countries: A systematic review," in Journal of Physics: Conference Series, 2018, vol. 978, no. 1, p. 012046: IOP Publishing.

[25] S. Petter, W. DeLone, and E. McLean, "Measuring information systems success: models, dimensions, measures, and interrelationships," European journal of information systems, vol. 17, no. 3, pp. 236-263, 2008.

[26] A. Subiyakto, D. Septiandani, E. Nurmiati, Y. Durachman, M. Kartiwi, and A. J. T. Ahlan, "Managers Perceptions towards the Success of E-Performance Reporting System," vol. 15, no. 3, pp. 1389-96, 2017.

[27] G. G. Gable, D. Sedera, and T. Chan, "Re-conceptualizing information system success: The IS-impact measurement model," Journal of the association for information systems, vol. 9, no. 7, p. 377, 2008.

[28] A. Subiyakto, A. R. Ahlan, M. Kartiwi, and S. J. Putra, "Measurement of the information system project success of the higher education institutions in Indonesia: a pilot study," International Journal of Business Information System, vol. 23, no. 2, pp. 229-247, 2016. 